\title{
THE DETERMINATION OF MACRO AND MICROELEMENTS IN CHAMOMILE TEAS (Matricaria chammomilla L.)
}

Sanja M. Petrović*, Saša R. Savić, Marina Lj. Dimitrijević, Živomir B. Petronijević

Faculty of Technology, University of Niš, Leskovac, Serbia

After water, tea is the most widespread beverage in the world. In addition to its use as a beverage, tea is also recognized as a drink that may have several health benefits, primarily due to the presence of nutritional elements. But, on the other hand, even very low concentrations of some metals could be toxic and can cause serious biological disorders and diseases. In this paper we investigated the content of micro and macroelements in chamomile tea samples found in a local market in Leskovac. The preparation of the samples was done by wet digestion. Element concentrations were determined by Inductively Coupled Plasma - Optical Emission Spectrometry (ICP-OES). Of all macroelements ( $\mathrm{Na}, \mathrm{Mg}, \mathrm{K}$ and $\mathrm{Ca}$ ), the potassium concentration was the highest in all investigated samples (18161 - $27985 \mathrm{mg} / \mathrm{kg}$ ). Comparing all heavy metals (copper, zinc, nickel, cadmium and lead) it was determined that the content of zinc was the highest in all samples, in the amount of $12.7-18.0 \mathrm{mg} / \mathrm{kg}$.
(ORIGINAL SCIENTIFIC PAPER) UDC 663.95:582.998.16:577.118

Keywords: Chamomile tea, ICP-OES, Micro and Macroelements

\section{Introduction}

Tea is one of the most popular and most widely consumed beverage in the world [1,2]. According to some estimates, about 20 billion tea cups are consumed in the world per day [3]. One of the main reasons for the popularity of tea is its positive impact on people's health, primarily due to the presence of nutritional elements $[4,5]$. Tea is defined as a mixture of crushed or comminuted plant parts, intended for internal or external use. Important tea ingredients are flavonoids, tannins, catechin, caffeine and theanine, as well as theobromine, theophylline and negligible amounts of carbohydrates, fats and proteins [1-6].

Chamomile (Matricaria chamomilla L.) is one of the most popular herbs. It is an annual plant with a branching stem and the height between 20 and $50 \mathrm{~cm}$. Only leaves and flowers of the plant are used for the tea preparation. Chamomile is used for irritability treatments, inner turmoil, ischemia, insomnia, mental malaise, fatigue, stomach diseases and intestines, kidneys, liver and gall bladder, as well as for treating some eye and various skin diseases. It is known that chamomile tea is rich in both organic and inorganic components. It is a good source of potassium, magnesium and iron $[7,8]$. However, except these metals, heavy metals can also be found in teas. Due to high toxicity of heavy metals and the tendency to accumulate in the ecosystem, they can be dangerous for all living organisms. The causes of heavy metal tea contamination can be the soil composition, present nutrients, fertilizers and others.

Heavy metals that can most likely be tea contaminates are: nickel, lead, cobalt and cadmium. According to the literature data, heavy metals can be present in various concentrations: $\mathrm{Ni}(2.46$ to $8.90 \mathrm{mg} / \mathrm{g}), \mathrm{Pb}(0.03$ to $14.8 \mathrm{mg} / \mathrm{g})$, Co (below the detection limit of $2.35 \mathrm{mg} / \mathrm{g}$ ) and $\mathrm{Cd}$ (below the detection limit of $0.37 \mathrm{mg} / \mathrm{g}$ ) $[1,7]$.

Bearing in mind the fact that some of the tea elements are essential (iron, zinc, copper, chromium (III), cobalt and manganese), or toxic (lead and mercury), metal determination in teas is very important in order to estimate the tea quality, as well as allowed concentration values that have no adverse influence on people's health. The content of certain metals in food is defined by the maximum concentration allowed, which represents the toxic substance quantity in an average adult $(70 \mathrm{~kg})$ that has no toxic effect throughout the whole life comsumation [9]. Metals as lead or cadmium have a particular impact on human health because they accumulate in the human body. High concentrations of these metals in the food are linked to the development of numerous diseases, especially cardiovascular, renal and nervous and the bone tissue. It was shown that these heavy metals are higly mutagenic and teratogenic [1]. The content of $\mathrm{Ag}, \mathrm{Al}, \mathrm{B}, \mathrm{Ba}, \mathrm{Bi}, \mathrm{Ca}, \mathrm{Cd}, \mathrm{Co}, \mathrm{Cr}, \mathrm{Cu}, \mathrm{Fe}, \mathrm{Ga}$, In, K, Li, Mg, Mn, Na, Ni, Pb, Sr, Tl and $\mathrm{Zn}$ in chamomile teas obtained from a local market in Leskovac is determined in this paper. The aim of the study is to determine the nutritive elements and trace elements content by using optical emission spectrometry with inductively coupled plasma as a source of excitation (ICP-OES).

\footnotetext{
*Author address: Sanja M. Petrović, Faculty of Technology,

16000 Leskovac, Bulevar oslobođenja 124, Serbia

E-mail: milenkovic_sanja@yahoo.com

The manuscript received: June, 01, 2015.

Paper accepted: June, 30, 2015
} 


\section{Experimental}

Reagents and standard solutions

Distilled water, purified by Fisher Chemical (HPLC grade) was used for samples dilution. The carrier gas was Argon 5.0 (99.999\% purity). In addition, the calibration standards were prepared for the above samples analysis. The multistandard IV - standard solution (Merck) which contained $\mathrm{Al}, \mathrm{Ag}, \mathrm{B}, \mathrm{Ba}, \mathrm{Be}, \mathrm{Cd}, \mathrm{Co}, \mathrm{Cr}, \mathrm{Cu}, \mathrm{Fe}, \mathrm{Mn}, \mathrm{Ni}, \mathrm{Pb}$,
$\mathrm{Se}, \mathrm{Ti}, \mathrm{V}$ and $\mathrm{Zn}$ at the concentration of $1000 \mathrm{ppm}$ was used for the preparation of calibration solutions. The preparation of standard solutions was performed by diluting the multistandard IV, so that the concentrations of standards for the calibration chart were in the range of expected test elements concentrations. Table 1 shows the wavelength detection of each element in the samples, a correlation coefficient $\left(R^{2}\right)$, the limit of detection (LOD), as well as the range of linearity.

Table 1. Calibration parameters: $\lambda ; R^{2} ; L O D$ and the range of linearity

\begin{tabular}{|c|c|c|c|c|}
\hline Element & $\begin{array}{c}\text { Detection } \\
\text { wavelength }(\mathrm{nm})\end{array}$ & $\begin{array}{c}\text { Correlation } \\
\text { coefficient }\left(R^{2}\right)\end{array}$ & $\begin{array}{l}\text { Limit of detection } \\
(\mu \mathrm{g} / \mathrm{L})\end{array}$ & $\begin{array}{l}\text { Linearity range } \\
(\mathrm{mg} / \mathrm{L})\end{array}$ \\
\hline $\mathrm{Ag}$ & $\begin{array}{l}224.641 \\
328.068\end{array}$ & $\begin{array}{l}0.99993 \\
0.99995\end{array}$ & 0.39 & $\begin{array}{c}0.0145-12.00 \\
0.000399-12.00\end{array}$ \\
\hline $\mathrm{Al}$ & $\begin{array}{l}167.078 \\
394.401\end{array}$ & $\begin{array}{l}0.99985 \\
0.99998\end{array}$ & $7.6 \times 10^{-2}$ & $\begin{array}{l}7.6 \times 10^{-5}-2.40 \\
0.00155-12.00\end{array}$ \\
\hline B & $\begin{array}{l}182.641 \\
249.773\end{array}$ & $\begin{array}{l}0.99999 \\
0.99999\end{array}$ & 6.43 & $\begin{array}{l}0.00737-12.00 \\
0.00643-12.00\end{array}$ \\
\hline $\mathrm{Ba}$ & 233.527 & 0.99995 & 0.183 & $0.000183-12.00$ \\
\hline $\mathrm{Bi}$ & $\begin{array}{l}190.241 \\
223.061\end{array}$ & $\begin{array}{l}0.99991 \\
0.99996\end{array}$ & 3.53 & $\begin{array}{l}0.00353-12.00 \\
0.00368-12.00\end{array}$ \\
\hline $\mathrm{Ca}$ & $\begin{array}{l}183.801 \\
396.847\end{array}$ & $\begin{array}{l}0.99995 \\
0.99946\end{array}$ & 2.14 & $\begin{array}{c}1.6-480.00 \\
0.00214-2.41\end{array}$ \\
\hline $\mathrm{Cd}$ & 214.438 & 0.99994 & 0.127 & $0.000127-12.00$ \\
\hline Co & 228.616 & 0.99980 & 0.327 & $0.000327-12.00$ \\
\hline $\mathrm{Cr}$ & 283.563 & 0.99998 & 0.435 & $0.000435-12.00$ \\
\hline $\mathrm{Cu}$ & $\begin{array}{l}224.700 \\
324.754\end{array}$ & $\begin{array}{l}0.99999 \\
0.99999\end{array}$ & 0.259 & $\begin{array}{l}0.000907-12.00 \\
0.000259-12.00\end{array}$ \\
\hline $\mathrm{Fe}$ & 259.941 & 0.99997 & 0.118 & $0.000118-12.00$ \\
\hline $\mathrm{Ga}$ & 417.206 & 0.99994 & 1.7 & $0.0017-12.00$ \\
\hline $\ln$ & 325.609 & 1.00000 & 4 & $0.004-12.00$ \\
\hline $\mathrm{K}$ & $\begin{array}{l}404.721 \\
766.491\end{array}$ & $\begin{array}{l}0.99998 \\
0.99999\end{array}$ & 0.378 & $\begin{array}{c}0.798-300.00 \\
0.000378-1.20\end{array}$ \\
\hline $\mathrm{Li}$ & $\begin{array}{l}323.261 \\
670.780\end{array}$ & $\begin{array}{l}1.00000 \\
0.99997\end{array}$ & $5.75 \times 10^{-2}$ & $\begin{array}{c}0.0798-12.00 \\
5.75 \times 10^{-5}-1.20\end{array}$ \\
\hline $\mathrm{Mg}$ & $\begin{array}{l}279.553 \\
285.213\end{array}$ & $\begin{array}{l}0.99997 \\
0.99994\end{array}$ & 0.115 & $\begin{array}{c}0.000115-6.04 \\
4.03-120.00\end{array}$ \\
\hline $\mathrm{Mn}$ & 257.611 & 0.99992 & $3.57 \times 10^{-2}$ & $3.57 \times 10^{-5}-12.00$ \\
\hline $\mathrm{Na}$ & $\begin{array}{l}330.237 \\
598.592\end{array}$ & $\begin{array}{l}0.99994 \\
0.99989\end{array}$ & 4.75 & $\begin{array}{c}7.98-480.00 \\
0.00475-12.00\end{array}$ \\
\hline $\mathrm{Ni}$ & 231.604 & 0.99994 & 0.474 & $0.000474-12.00$ \\
\hline $\mathrm{Pb}$ & 220.353 & 0.99998 & 1.78 & $0.00178-12.00$ \\
\hline $\mathrm{Sr}$ & 407.771 & 0.99998 & $6.23 \times 10^{-3}$ & $6.23 \times 10^{-6}-2.41$ \\
\hline $\mathrm{Tl}$ & 190.864 & 0.99998 & 1.72 & $0.00172-12.00$ \\
\hline $\mathrm{Zn}$ & 213.856 & 0.99997 & $8.2 \times 10^{-2}$ & $8.2 \times 10^{-5}-12.00$ \\
\hline
\end{tabular}

Table 2. Operating conditions for ICP-OES (W)

\begin{tabular}{cc}
\hline Plasma Power (W) & 1400 \\
\hline Gas flow (L/min) & 13 \\
-Coolant & 0.80 \\
-Auxiliary & Cross flow \\
Nebulizer type & 0.95 \\
Nebuliser flow rate (L/min) & 30 \\
Pump speed (rpm) & 0 \\
Stabilization time (s) & 3 \\
Number of probes for each \\
measuring
\end{tabular}


Sampling and sample preparation

Samples of chamomile teas were taken from different manufacturers (Chamomillae flos) in November 2014 from a local market in Leskovac. The preparation of chamomile tea samples was carried out by wet digestion. A chamomile tea sample $(2 \mathrm{~g})$ was added with 98 $\mathrm{ml}$ of boiling water. $25 \mathrm{ml}$ of the sample was then taken and filtered after 5, 10 and 15 minutes of stirring. The filtered samples were diluted with another $25 \mathrm{~mL}$ of distilled water. After dilution, the samples were subjected to ICP-OES analysis.

Analysis of samples

The quantitative analysis of all samples was per- formed on ICP-OES (Inductively Coupled Plasma - Optical Emission Spectrometry, ARCOS FHE12, SPECTRO, Germany), according to the manufacturer's instructions. The instrument conditions and determined parameters are given in Table 2 .

\section{Results and discussion}

Testing results of micro and macro elements in five different tea samples produced by different manufacturers and purchased at a local market in Leskovac are shown in Table 3.

Table 3. Measuring results of the metal presence in the tea samples (Matricaria chammomilla L.) $(\mathrm{mg} / \mathrm{kg})$.

\begin{tabular}{|c|c|c|c|c|c|c|c|c|c|c|c|c|c|c|c|}
\hline \multirow[b]{2}{*}{$\begin{array}{l}\text { Time, } \\
\text { min }\end{array}$} & \multicolumn{3}{|c|}{ Manufacturer I } & \multicolumn{3}{|c|}{ Manufacturer II } & \multicolumn{3}{|c|}{$\begin{array}{l}\text { Manufacturer III } \\
\text { Elements content. ma/kg }\end{array}$} & \multicolumn{3}{|c|}{ Manufacturer IV } & \multicolumn{3}{|c|}{ Manufacturer V } \\
\hline & 5 & 10 & 15 & 5 & 10 & 15 & 5 & 10 & 15 & 5 & 10 & 15 & 5 & 10 & 15 \\
\hline $\mathrm{Ag}$ & 0.00 & 0.00 & 0.00 & 0.00 & 0.00 & 0.00 & 0.00 & 0.00 & 0.00 & 0.00 & 0.00 & 0.00 & 0.00 & 0.00 & 0.00 \\
\hline $\mathrm{Al}$ & 3.40 & 4.20 & 2.50 & 9.40 & 9.90 & 9.90 & 4.50 & 3.90 & 4.40 & 4.80 & 4.90 & 5.80 & 5.10 & 4.60 & 4.90 \\
\hline B & 13.8 & 14.2 & 9.30 & 16.8 & 16.6 & 16.4 & 15.9 & 15.7 & 12.9 & 13.0 & 12.7 & 7.90 & 6.40 & 15.5 & 15.1 \\
\hline $\mathrm{Ba}$ & 3.90 & 4.10 & 3.50 & 3.90 & 3.90 & 3.90 & 3.80 & 3.80 & 3.80 & 3.90 & 3.90 & 4.90 & 4.50 & 3.70 & 3.80 \\
\hline $\mathrm{Bi}$ & 3.50 & 3.50 & 3.50 & 3.30 & 3.40 & 3.40 & 3.40 & 3.40 & 3.40 & 3.40 & 3.40 & 3.50 & 3.30 & 3.30 & 3.40 \\
\hline $\mathrm{Ca}$ & 2814 & 3179 & 2325 & 2138 & 2258 & 2324 & 2960 & 2948 & 2599 & 2468 & 2483 & 2046 & 1667 & 3139 & 3356 \\
\hline $\mathrm{Cd}$ & 0.00 & 0.00 & 0.00 & 0.10 & 0.00 & 0.00 & 0.00 & 0.10 & 0.10 & 0.00 & 0.10 & 0.10 & 0.10 & 0.00 & 0.00 \\
\hline Co & 0.00 & 0.00 & 0.00 & 0.00 & 0.00 & 0.00 & 0.00 & 0.00 & 0.00 & 0.00 & 0.00 & 0.00 & 0.00 & 0.00 & 0.00 \\
\hline $\mathrm{Cr}$ & 0.00 & 0.00 & 0.00 & 0.00 & 0.00 & 0.00 & 0.00 & 0.00 & 0.00 & 0.00 & 0.00 & 0.00 & 0.00 & 0.00 & 0.00 \\
\hline $\mathrm{Cu}$ & 6.30 & 7.30 & 4.70 & 6.30 & 6.40 & 6.30 & 6.70 & 6.60 & 7.10 & 7.70 & 7.70 & 7.00 & 5.70 & 7.00 & 7.00 \\
\hline $\mathrm{Fe}$ & 1.90 & 2.20 & 1.50 & 6.00 & 7.00 & 7.40 & 2.90 & 2.50 & 3.10 & 3.20 & 2.90 & 3.00 & 2.30 & 2.70 & 3.10 \\
\hline $\mathrm{Ga}$ & 0.20 & 0.20 & 0.20 & 0.20 & 0.20 & 0.20 & 0.20 & 0.20 & 0.20 & 0.20 & 0.20 & 0.20 & 0.20 & 0.20 & 0.20 \\
\hline In & 2.10 & 2.10 & 2.00 & 2.80 & 2.80 & 2.80 & 2.20 & 2.10 & 2.70 & 2.80 & 2.80 & 3.50 & 3.10 & 2.30 & 2.10 \\
\hline $\mathrm{K}$ & 22042 & 21979 & 18161 & 27223 & 25926 & 26008 & 27489 & 27134 & 25050 & 25789 & 25371 & 25071 & 23617 & 27985 & 26968 \\
\hline $\mathrm{Li}$ & 1.10 & 1.10 & 1.00 & 0.50 & 0.50 & 0.50 & 0.90 & 0.90 & 0.90 & 0.90 & 0.80 & 0.60 & 0.60 & 0.90 & 0.90 \\
\hline $\mathrm{Mg}$ & 2127 & 2275 & 1624 & 1907 & 1872 & 1898 & 2241 & 2176 & 2414 & 2390 & 2367 & 1760 & 1506 & 2365 & 2362 \\
\hline $\mathrm{Mn}$ & 9.30 & 9.60 & 7.80 & 26.1 & 26.9 & 28.2 & 12.9 & 12.6 & 24.4 & 25.1 & 23.8 & 42.8 & 33.3 & 14.2 & 14.7 \\
\hline $\mathrm{Na}$ & 2186 & 2331 & 1687 & 543 & 582 & 516 & 1974 & 1886 & 4151 & 4166 & 4111 & 591 & 515 & 1873 & 1886 \\
\hline $\mathrm{Ni}$ & 0.00 & 0.00 & 0.00 & 0.20 & 0.30 & 0.30 & 0.00 & 0.00 & 0.00 & 0.00 & 0.00 & 0.50 & 0.10 & 0.00 & 0.00 \\
\hline $\mathrm{Pb}$ & 0.50 & 0.60 & 0.20 & 0.30 & 0.40 & 0.20 & 0.40 & 0.40 & 0.30 & 0.20 & 0.20 & 0.30 & 0.20 & 0.30 & 0.20 \\
\hline $\mathrm{Sr}$ & 13.7 & 17.4 & 7.2 & 12.9 & 13.6 & 12.4 & 13.9 & 14.3 & 14.1 & 14.0 & 15.5 & 16.2 & 13.7 & 13.2 & 14.4 \\
\hline $\mathrm{TI}$ & 0.20 & 0.20 & 0.20 & 0.20 & 0.20 & 0.20 & 0.20 & 0.20 & 0.20 & 0.20 & 0.20 & 0.20 & 0.20 & 0.20 & 0.20 \\
\hline $\mathrm{Zn}$ & 15.1 & 17.5 & 12.7 & 15.6 & 16.0 & 15.3 & 17.3 & 17.1 & 15.5 & 16.3 & 16.5 & 18.0 & 17.3 & 16.1 & 16.0 \\
\hline
\end{tabular}

Based on the obtained results, it can be concluded that the presence of silver, cobalt and chromium was not detected in any sample, ie. their content in the samples was below the detection limit (Table 3). Of all macroelements ( $\mathrm{Na}, \mathrm{Mg}, \mathrm{K}$ and $\mathrm{Ca}$ ) the most present was potassium, followed by sodium, calcium and magnesium. Potassium is higly important because it is necessary for upkeep of the acid-base balance in the body, as well as the osmotic pressure. It plays an important role in the nerve impulse transmission of the muscle contraction because it has the ability to increase the muscle and nerve cells excitability. Also, potassium has an impact on carbohydrate metabolism and membrane transport [10]. The content of potassium in the tea samples was in the interval from 18161 to $27985 \mathrm{mg} / \mathrm{kg}$. The recommended daily intake of potassium varies from $0.4 \mathrm{~g}$ for infants, $3.8 \mathrm{~g}$ for children aged 4-8 to $4.7 \mathrm{~g}$ for adolescents, women and men (Institute of Medicine, 2004). The lack of potassium affects hypertension, cardiac arrhythmia, nausea, drowsiness, muscle weakness, reduced hoses mobility, lethargy, etc. Sodium, along with potassium participates in the transfer of nerve impulses, affects the permeability of the membrane and maintains the muscle tone. The lack of sodium in the body can cause a fall in blood pressure, which can lead to general weakness and loss of appetite [10]. The sodium content in tea samples was in the interval from 515 to 4166 $\mathrm{mg} / \mathrm{kg}$. The recommended daily intake for infants is $0.12 \mathrm{~g}$, for children aged 4-8 and $1.2 \mathrm{mg}$ for adolescents, men and women about $1.5 \mathrm{~g}$ (Institute of Medicine, 2004). Calcium is an essential constituent of bones and teeth, and has a very important role in the blood plasma and cellular membranes. Calcium deficiency leads to osteomalacia and osteoporosis in adults [11], and rachitis in children. The required average daily dose for calcium is $1000 \mathrm{mg}$. The presence of calcium in tea samples was in the range from 1667 to $3356 \mathrm{mg} / \mathrm{kg}$. The recommended daily intake of Ca for infants is $210 \mathrm{mg}$, for children aged 4-8 years 800 $\mathrm{mg}, 1300 \mathrm{mg}$ for adolescents and for men and women 
from 1000 to $1200 \mathrm{mg}$, depending on the age (Institute of Medicine, 1997). Magnesium participates in many biochemical and physiological processes in the body. It is necessary for the normal function of many different enzymes [12]. It is present in bones, tissues, organs and blood. It is also nessesery for normal muscles and nervous system functioning, supports immunity, makes bones strong and promotes a normal heart rhythm. The detected presence of magnesium in the tea samples was in the interval from 1506 to $2414 \mathrm{mg} / \mathrm{kg}$. The recommended daily intake of $\mathrm{Mg}$ for infants is $30 \mathrm{mg}$, for children aged $4-8$ and $130 \mathrm{mg}$ for adolescents, men and women about $400 \mathrm{mg}$ (Institute of Medicine, 1997). The magnesium deficiency causes a variety of neurological and neuromuscular signs (cramps, pausing and altered muscle reflexes), and affects arrhythmia and myocardial infarction [12]. In addition, magnesium regulates the sugar level in blood, affects the blood pressure [13], and plays an important role in the blood pressure regulation [14]. Magnesium plays an important role in the carbohydrate metabolism and is considered to be an appropriate protective component for the Type II diabetes, which affects the release and activity of insulin, the hormone that controls blood sugar levels. It is also known that a high magnesium intake in the body reduces the risk of stroke [15]

High potassium, magnesium and sodium levels in all tested samples of chamomile tea are probably due to their high presence in the soil. It is well known that the main source of metals in food comes from the land on which nutritious products are grown. That brings a clear connection between the soil composition and metals which get into the human body. The average potassium, magnesium and sodium values are 15000, 9000 and $12000 \mathrm{mg} / \mathrm{kg}$, respectively [16].

From the group of trace elements, the presence of iron, copper, zinc and manganese were detected in all tea samples. The iron content was 1.9 to $7.4 \mathrm{mg} / \mathrm{kg}$. Iron, one of the most important trace elements, is an integral part of hemoglobin, mioglobulina and respiratory enzymes [17]. It has the ability to increase resistance to disease and prevents fatigue and anemia. The symptoms of iron deficiency can cause the feeling of tiredness, poor appetite and reduced organism resistance [10].

The presence of copper in tea samples was also detected. Copper is typically bound to the enzyme polyphenol oxidase in tea drinks [1]. The copper concentration in the assay camomile tea samples was in the range of 4.7 to $7.7 \mathrm{mg} / \mathrm{kg}$, which is consistent with the literature data where the obtained amount was between 2 and $20 \mathrm{mg} /$ $\mathrm{kg}$ [18]. The lack of copper has the effect of anemia, hair depigmentation and bones deformities.

The amounts of zinc in all samples were between 12.7 and $18.0 \mathrm{mg} / \mathrm{kg}$, which is less than a usual concentration in tea $(28.2 \mathrm{mg} / \mathrm{kg})$ [19]. Zinc is the essential biomembrane component and it is necessary for its normal function. It is also necessary for the metabolism of proteins and carbohydrates, prostate function, and many other biological functions. Recent studies have shown that zinc is important for the brain function, and the treatment of mental disorders (eg, schizophrenia). It is required for DNA synthesis and plays a major role in the development and functioning of reproductive organs. In addition, zinc is an essential oligoelement, important for the membrane stabilization and the activity of metalloenzymes. About 70 different metalloenzymes contain zinc: superoxide dismutase, carbonic anhydrase, lactate dehydrogenase, alkaline phosphatase, alcohol dehydrogenase, as well as RNA and DNA polymerases $[10,21]$. Zinc deficiency leads to endothelial membrane damage [20]. Zinc increases the number of $T$ defensive cells and their efficiency and helps in the treatment of infertility, stomach and wound healing. According to the well-known data, the lack of this vital element is common in $48 \%$ of all global population [22].

The obtained values for the manganese content (7.8$42.8 \mathrm{mg} / \mathrm{kg}$ ) were lower than the average manganese concentrations in Pakistan teas of $175 \mathrm{mg} / \mathrm{kg}$ [19]. Manganese participates in a lipid metabolism, bone formation, connective tissue disorders, energy production and nucleotides synthesis of DNA. The patients with iron deficiency can have the increased manganese resorption which can lead to intoxication. Manganese deficiency in the body causes loss of appetite, drowsiness and muscle pain, and sometimes hallucinations.

The presence of lithium in all analyzed samples was detected in the range of 0.5 to $1.1 \mathrm{mg} / \mathrm{kg}$. Lithium is present in a small quantity in the tissues and body fluids and it is difficult to diffuse through the cell membrane [10]. It plays an important role in some enzymes functioning (hexokinase, pyruvate kinase, etc.), such as keeping potassium / sodium balance in the body.

The presence of boron was detected in the range of 9.3 to $16.8 \mathrm{mg} / \mathrm{kg}$. The biological role of boron in humans is not yet fully understood, and it is still in the testing phase. So far, no evidence of boron toxicity has been found [23]. Studies of Murray (1995) showed that boron absorbtion is fastest via gastrointestinal tract, up to $90 \%$ [24]. In blood, boron is in the form of free boric acid and is considered to have a regulatory role for some enzymes [25]. Some clinical studies of women's health have shown that due to the boron lack the development of osteoporosis in the climax is possible. Also, the absence of this element may cause attention disorders and short-term memory [26].

In the tea samples, aluminum was detected in the amount between 2.5 and $9.9 \mathrm{mg} / \mathrm{kg}$. Previously, there was no evidence of aluminum function in metabolism. In some organisms, the reaction between cytochrome c and succinyl dehydrogenase is determined by Al. Aluminium is also a cofactor in the guanine nucleotide binding which is necessary for the metabolism of protein. On the other hand, the increased content of this element in patients that suffer from kidneys diseases can significantly damage the skeleton due to the negative impact on the process of the bone formation, leading to occurrence of osteomalacia. 
The nickel concentration in all samples was less than $0.3 \mathrm{mg} / \mathrm{kg}$, which is less than its usual concentration (between 2.9 and $22.6 \mathrm{mg} / \mathrm{kg}$ ) [19]. The role of nickel has not been fully explored yet. It is known that it helps in pancreatic function and insulin production [10].

Heavy metals are a special group of elements with the density between 3.5 and $5 \mathrm{~g} / \mathrm{cm}^{3}$. Cadmium was detected in several tea samples in the amount of $0.1 \mathrm{mg} / \mathrm{kg}$. The high Cd level in kidney may cause a tissue damage, which further leads to kidney stones formation and pressurization. Cadmium has influence on the bone structure and bone deformation. Also, cadmium is a carcinogen that has a damaging influence on the heart and kidney. A norminative cadmium concentration in teas is not prescribed.

In addition to cadmium, the lead presence was also detected in all samples in the range of 0.2 to $0.6 \mathrm{mg} /$ $\mathrm{kg}$, which is below the maximum allowed value for tea samples $(2 \mathrm{mg} / \mathrm{kg})$ [1]. Lead is stored in the bones and in smaller portions in the liver, kidneys and soft tissues. Lead poisoning affects the brain function and nervous system, reduces the level of intelligence, perception and memory mode. The most severe forms can cause death. Lead can originate from fertilizers (zinc sulfate, which is used to ensure enough of micronutrients and copper oxychloride, which is used as a fungicide), presented as impurity. Also, in the vicinity of roads tea plants are more exposed to lead contamination. If the grown land of tea plants is usually acidic, this affects the increased mobility and metal adoption are more expressed.

\section{Conclusion}

Finally, based of the results obtained in this work, the presence of micro and macro elements in chamomile tea samples were within the permitted limits, including the presence of heavy metals. All tested chamomile tea samples showed high macro element concentrations that can fullfill the daily needs of these nutrients.

\section{Acknowledgements}

This work was supported by the Ministry of Education and Science of the Republic of Serbia under Project No.TR 34012.

\section{References}

[1] A. Perić-Grujić, V. Pocajt, M. Ristić, Određivanje sadržaja teških metala u čajevima sa tržišta u Beogradu, Srbija, Hemijska Industrija, 63(5) (2009) 433 - 436.

[2] T. K. Mondal, A. Bhattacharya, M. Laxmikumaran, P. S. Ahuja, Recent advances of tea (Camelia sinesis) Biotechnology, Plant Cell Tissue and Organ Culture, 76 (2004) $195-254$.

[3] S. Seenivasan, N. Manikandan, N. N. Muraleedharan, R. Selvasundaram, Heavy metal content of black teas from south India, Food Control, 19 (2008) 746 - 749.

[4] P. Fernandez-Caceres, M. J. Martin, M. Pablos, A. G. Gonzalez, Differentiation of tea (Camellia sinensis) varieties and their georaphical origin according to their metal content, Journal of Agricultural and Food Chemistry, 49 (2001) $4775-4779$.

[5] W. Z. Han, Y.Z. Shi, L. F. Ma, J. Y. Ruan, Arsenic, Cadmium, Chromium, Cobalt, and Copper in different types of Chinese tea, Bulletin of Environmental Contamination and Toxicology, 75 (2005) $272-277$.

[6] P. Pohl, B. Prusisz, Fractination analysis of manganese and zinc in tea infusions by two-column solid phase extraction and flama atomic absorption spectrometry, Food Chemistry, 102 (2007) 1415 - 1424.

[7] L. Nováková, A. Vildová, J. P. Mateus, T. Gonçalves, P. Solich, Development and application of UHPLC-MS/MS method for the determination of phenolic compounds in Chamomile flowers, Talanta, 82 (2010) 1271 - 1280.

[8] S.Pavlović, P.Živanović, Sistematika lekovitih biljaka, Zavod za udžbenike i nastavna sredstva, Beograd, 1982.

[9] M. M. Özcan, A. Ünver, T. Uçar, D. Arslan, Mineral content of some herbs and herbal teas by infusion and decoction, Food Chemistry, 106 (2008) 1120 - 1127.

[10] D. Veljković, G. N. Vučković, Minerali u ishrani, Hemijski pregled, 51 (2010) $14-19$.

[11] J. N. Hathcock, Vitamin and Mineral Safety, in Council for Responsible Nutrition, 2nd Edition, CRN Press, Washington, 2004.

[12] M. E. Shils, Magnesium, in Moderan nutrition in health and diease, M. E. Shils, J. A. Olson, M. Shike, C. A. Ross, 9th Edition, Wiliams \& Wilkins, Philadelphia, 1999, pp. $169-192$.

[13] N. E. Saris, E. Mervaala, H. Karppanen, J. A. Khawaja, A. Lewenstam, Magnesium: an update on physiological, clinical, and analytical aspects, Clinica Chimica Acta, 294 (2000) $1-26$.

[14] IOM, Institute of Medicine, Food Nutrition Board. Dietary Reference Intakes: Calcium, Phosphorus, Magnesium, Vitamin D. National Academy Press, Washington, 1999.

[15] A. Ascherio, E. B. Rimm, M. A. Hernana, E. L. Giovannucci, I. Kawachi, M. J. Stampfer, W. C. Willett, Intake of Potassium, Magnesium, Calcium, and Fiber and Risk of Stroke Among US Men, Circulation, 98 (1998) 1198 1204.

[16] D. Velimirović, Optimizacija, validacija i primena ICP-OES metode određivanja sadržaja metala u realnim uzorcima, Doktorska disertacija, PMF, Univerzitet u Nišu, 2013.

[17] N. Tasid, Dj. Radak, Z. Cvetković, B. Petrović, N. Ilijevski, G. Djordjevid-Debid, Uloga i značaj oligoelemenata u patogenezi arteroskleroze, Vojnosanitetski pregled, 61 (2004) $667-673$.

[18] A. Mehra, C. L. Baker, Leaching and bioavailability of aluminium, copper and manganese from tea (Camelia sinensis), Food Chemistry, 100 (2007) 1456 - 1463.

[19] A. Marcos, A. Fisher, G. Rea, S. J. Hill, Preliminary study using trace element concentrations and a chemometrics approach to determine the geographical origin of tea, Journal of Analytical Spectrometry, 13 (1998) 521 - 525.

[20] W. Leonardth, T. Kurktschiev, D. Meissner, P. Lattke, C. Abletshauser, G. Weidinger, W. Jaross, M. Hanefeld, Effects of fluvastatin therapy on lipids, antioxidants, oxidation of low density lipoproteins and trace metals, European Journal of Clinical Pharmacology, 53 (1997) $65-69$. 
[21] M. Radojković, Ekstrakti duda (Morus spp., Morasceae), sastav, delovanje i primena, doktorska disertacija, Tehnološki fakultet, Univerzitet u Novom Sadu, 2012.

[22] P. Oteiza, G. Mackenzie, Zinc, oxidant-triggered cell signaling and human health, Molecular Aspect of Medicine, 26 (2005) $245-255$.

[23] F. J. Murray, A human health risk assessment of boron (boric acid and borax) in drinking water, Regulatory Toxicology and Pharmacology: RTP, 22(3) (1995) 221 230.
[24] C. D. Hunt, Regulation of enzymatic activity, Biological Trace Element Research, 66(1) (1998) 205 - 225.

[25] J. G. Penland, The importance of boron nutrition for brain and psychological function, Biological trace element research, 66(1) (1998) $299-317$.

[26] Pravilnik o količinama pesticida, metala i metaloida i drugih otrovnih supstancija, hemioterapeutika, anabolika i drugih supstancija koje se mogu nalaziti u namirnicama, Službeni list SRJ br. 5/92.

Izvod

\section{ODREĐIVANJE MAKRO I MIKRO ELEMENATA U ČAJEVIMA OD KAMILICE (Matricaria chammomilla L.)}

Sanja M. Petrović, Saša R. Savić, Marina Lj. Dimitrijević, Živomir B. Petronijević

Posle vode, čaj je najrasprostranjeniji napitak širom sveta. Osim ove upotrebe, čaj se takođe dugo koristi u preventivne i terapeutske svrhe, posebno zbog prisustva nutritivnih elemenata. Međutim, prisustvo nekih metala čak i u malim koncentracijama može biti toksično i dovesti do ozbiljnih poremećaja i oboljenja. U radu je određen sadržaj mikro i makro elemenata u uzorcima čaja od kamilice. Priprema uzoraka vršena je mokrom digestijom. Koncentracije odabranih metala u rastvorima posle digestije određene su primenom optičke emisione spektrometrije sa indukovano spregnutom plazmom (ICP-OES). Od ispitivanih makroelemenata ( $\mathrm{Na}$, $\mathrm{Mg}, \mathrm{K}$ i Ca) u ispitivanim uzorcima je primećen najveći sadržaj kalijuma (1816127985 mg/kg), dok je sadržaj teških metala (bakar, cink, mangan, nikl, kadmijum i olovo) detektovan u dozvoljenim granicama. U svim uzorcima utvrđen je najveći sadržaj cinka (12,7 - $18 \mathrm{mg} / \mathrm{kg})$.
Ključne reči: čaj od kamilice, ICP-OES, mikro i makroelementi 